\title{
RAFFLESIA BANAHAW (RAFFLESIACEAE), A NEW SPECIES FROM LUZON, PHILIPPINES
}

\author{
JULIE F. BARCELONA ${ }^{1}$, PIETER B. PELSER ${ }^{2} \&$ MARYANN O. CAJANO $^{3}$
}

\begin{abstract}
SUMMARY
A new small-flowered species of Philippine Rafflesia from Mt Banahaw in Luzon is described. Rafflesia banahaw is the seventh endemic species of Rafflesia found in the Philippines. It resembles $R$. baletei, but is different in, amongst other characters, having more confluent wart ornamentations, more numerous and densely packed processes on the disk, and more numerous, slightly immersed anthers. In addition, $R$. banahaw has glabrous ramenta which are grouped in dense clusters on the inside of the diaphragm and are more or less solitary on the inside of the perigone tube, whereas the ramenta of $R$. baletei are pubescent and distributed more uniformly.
\end{abstract}

Key words: Rafflesiaceae, Rafflesia, Philippines, Mt Banahaw, conservation, taxonomy.

\section{INTRODUCTION}

Rafflesia R.Br. (Rafflesiaceae or Euphorbiaceae sensu Davis et al., 2007) is a holoparasitic genus from western Malesia (Meijer, 1997; Nais, 2001) that grows on the roots and stems of Tetrastigma species (Vitaceae). Recent fieldwork on Mt Banahaw on the island of Luzon, Philippines by members of the environmental advocacy organization, Tanggol Kalikasan, has resulted in the discovery of a new species of Rafflesia which we formally describe here. This brings the total number of accepted Rafflesia species to 23 .

For more than a century, only two Rafflesia species were known from the Philippines: $R$. manillana Teschem. and $R$. schadenbergiana Göpp. ex Hieron. In the past five years, however, five additional species names have been published: $R$. speciosa (Barcelona \& Fernando, 2002), R. mira (Fernando \& Ong, 2005), R. magnifica (Madulid et al., 2006), R. baletei (Barcelona et al., 2006), and R. lobata (Galang \& Madulid, 2006). After examination of the types of $R$. mira Fernando \& Ong and $R$. magnifica Madulid, Tandang \& Agoo and comparing thier protologues, we conclude that the two species are synonymous and $R$. mira has nomenclatural priority. Despite the publication date on the protologue of 2005, R. magnifica was effectively published in 2006, six months later than R. mira. Both names were based on specimens collected from Mt Candalaga,

1) Philippine National Herbarium (PNH), Botany Division, National Museum of the Philippines, P. Burgos St., P.O. Box 2659, Manila, Philippines; e-mail: barceljf@hotmail.com.

2) Miami University, Botany Department, 316 Pearson Hall, Oxford, Ohio, USA; e-mail: pelserpb@muohio.edu.

3) College of Agriculture Herbarium, Museum of Natural History, University of the Philippines Los Baños, College, Laguna 4031, Philippines; e-mail: maocajano@yahoo.com. 
Compostela Valley in Mindanao Island. The Banahaw taxon is the seventh Philippine Rafflesia species and the third species of the genus described from Luzon. At the time of writing, two additional species are being described from north-eastern Luzon (Co et al., in prep.; Barcelona et al., in prep.) and photographic evidence points at the existence of an additional potential new species in Mindanao. If these names are published and are accepted as new species, the number of Philippine Rafflesia would reach ten, making the Philippines the country with the highest number of Rafflesia.

\title{
Rafflesia banahaw Barcelona, Pelser \& Cajano, spec. nov. - Fig. 1; Plate 1
}

\begin{abstract}
Rafflesiae baletei morphologiam generatim et diametram relative aperturae diaphragmataeque similis, sed differt ornamentis verrucatis confluentioribus, processibus ramosioribus conspicue et numerosioribus, ramentibus glabris fasciculos in diaphragmate quam in tubo perigonii densioribus facientibus, antheris numerosioribus minus expositis. - Typus: Barcelona, Cajano \& Mendua 3345 (holo, open male flower, $\mathrm{PNH}$; iso, mature male bud, CAHUP), Philippines, Luzon, Quezon Province, Dolores Municipality, Barangay Kinabuhayan, Mt Banahaw.
\end{abstract}

Mature buds to $11 \mathrm{~cm}$ diameter. Basal cupule 1-1.5 cm high, c. $4 \mathrm{~cm}$ wide. Bracts (or bud scales) in three imbricate whorls, outermost smallest, $3-4$ by $5-6 \mathrm{~cm}$, innermost largest, 11-13 by $9.5-11 \mathrm{~cm}$, orbicular to broadly elliptic, whitish when still beneath the basal cupule becoming dark chocolate brown after emergence, margins entire. Flowers $17.5-27 \mathrm{~cm}$ diam. when fully expanded, to $15 \mathrm{~cm}$ high. Perigone tube 5-6.5 $\mathrm{cm}$ long, floor velutinous. Perigone lobes 5, orbicular to broadly orbicular, basal half slightly erect, apical half recurved, $5-11$ by $6.5-12 \mathrm{~cm}, 1-1.5 \mathrm{~cm}$ thick at base, dark reddish or maroon, less frequently orange, becoming darker with age, margins with a narrow band of white, concolorous with the rim of the diaphragm aperture, upper surface warty, warts dense, prominent, variably-shaped, sometimes confluent, often longer than wide, powdery white when fresh, becoming concolorous with background with age. Diaphragm 8-12 cm diam., $2.5-4.5 \mathrm{~cm}$ wide from aperture rim to base of perigone lobe, 7-10 mm thick at base, becoming thinner towards the aperture, concolorous with perigone, warts thin with blunt whitish tips forming variably-shaped impressions of the perigone warts, windows absent. Aperture 3.5-6.5 cm diam., rim whitish. Disk 6-8.5 cm diam., c. $1 \mathrm{~cm}$ thick at the centre, nearly flat in male flowers to slightly dome-shaped in female flowers with a sharply raised margin, pale yellow or yellowish cream centrally, maroon along the margin, margin irregularly and shallowly incised or crenulate, corona bluntly tuberculate, sparsely pubescent, maroon. Processes up to c. 25 in number, variably branched, dark maroon, tips darker, laterally compressed, sparsely and shortly pubescent, those at the centre longest, to $1.5 \mathrm{~cm}$ long, in three concentric rings, peripheral ones reduced to tubercles, these tubercles also scattered among the central processes. Column to $6.5 \mathrm{~cm}$ from the base of cupule to the upper surface of disk. Neck of column c. $1 \mathrm{~cm}$ long in male flowers, markedly shorter or nearly absent in female flowers, $3-5 \mathrm{~cm}$ diameter. Ramenta to $3 \mathrm{~mm}$ long, glabrous, polymorphic in shape, branching pattern, and size, those in the perigone tube scattered, more or less solitary and less-branched, those on the inside of the diaphragm clustered, larger, stouter and denser becoming sparse and nearly absent in about a $3 \mathrm{~mm}$ radius around the aperture rim. Male flower without a vestigial ovary. Anthers 14-16 (c. 23 in a partially deteriorated large flower), semi-globular, $2-4$ by c. $5 \mathrm{~mm}$, deeply immersed 


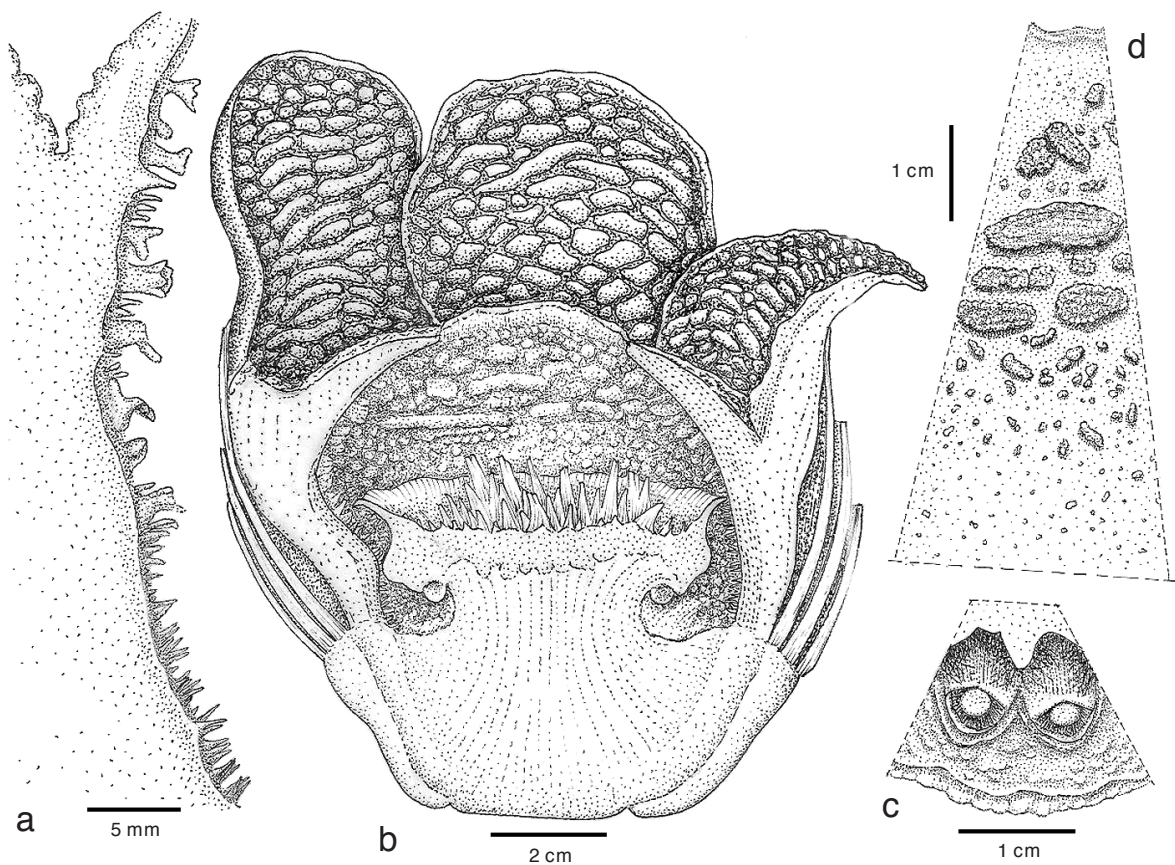

Fig. 1. Rafflesia banahaw Barcelona, Pelser \& Cajano. a. Longitudinal section of the floral tube showing the morphology and distribution of ramenta in lateral view; b. longitudinal section of an open flower; c. two anthers; d. face view of the ramenta on the inner surface of the diaphragm and perigone tube (all: Barcelona, Cajano \& Mendua 3345).

in anther sulci that are $1-1.3$ by $7-8 \mathrm{~mm}$, whitish and glabrous around the anthers, becoming orange red and velutinous towards the column neck. Female flower as big as the male, having no vestigial anthers, ovaries of the specimens seen too deteriorated to determine size and morphology.

Distribution - Philippines: Luzon Island, Quezon Province, Mt Banahaw.

Habitat \& Ecology - Known from five populations in recovering disturbed lowland dipterocarp rain forest on Mt Banahaw at 720-750 m elevation. Rafflesia banahaw grows on Tetrastigma roots below, at or above ground level, but has not been observed on the aerial stems of the host plant. It generally grows in disturbed areas with dense herbaceous covering or thick leaf litter, on well-drained sandy soil, sometimes on steep slopes and beside seasonal creeks and rivers. Canopy trees and emergents in the immediate vicinity of the Rafflesia populations consist of Alstonia, Dysoxylum, Parashorea, Pterocarpus indicus, Shorea, and Swietenia macrophylla, of which the largest $\mathrm{dbh}$ measures c. $1.5 \mathrm{~m}$. The subcanopy is dominated by escaped Coffea from a nearby plantation mixed with, among others, Artocarpus, Dendrocnide, Ficus, and Macaranga. The herbaceous layer is dominated by Tradescantia zebrina and Pollia in association with Ardisia, Calanthe, Colocasia, Cyrtandra, Plectranthus, Selaginella, Setaria, and ferns in the genera Asplenium, Bolbitis, Leptochilus, Microsorum, Sphaerostephanos, and Tectaria. 

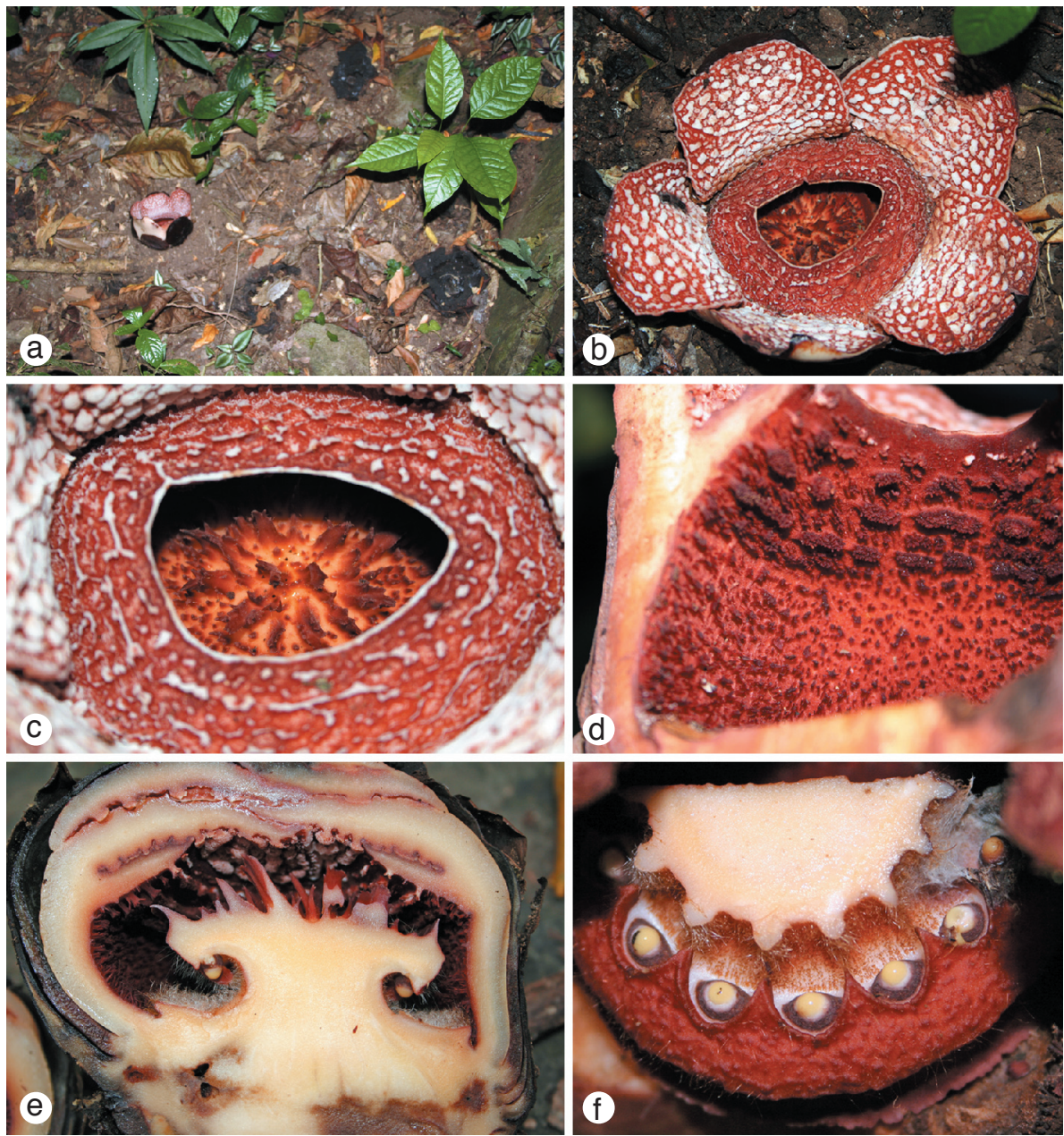

Plate 1. Rafflesia banahaw Barcelona, Pelser \& Cajano. a. Habitat showing flower just opening (left) and senescent flower (right); b. a newly-open male flower; c. diaphragm opening through which is visible the processes on the top surface of the disk; $d$. ramenta on the inner surface of the diaphragm and perigone tube; e. column (cut surface of neck at bottom) showing anthers below the disk corona; f. longitudinal section of a male floral bud (a-d, f: Barcelona, Cajano \& Mendua 3345 (holotype); e: Barcelona, Cajano \& Mendua 3345 (isotype)). - Photos: J.F. Barcelona.

\section{DISCUSSION}

\section{Morphological affinities}

Rafflesia banahaw is one of the four small-flowered Philippine Rafflesia species. It is easily distinguished from $R$. manillana from Mt Makiling and a few other locations in Luzon by its larger size and narrower diaphragm aperture. The flowers of $R$. manillana are $15-20 \mathrm{~cm}$ diameter and the diaphragm aperture is much wider than the diameter of the disk. In contrast, $R$. banahaw flowers are $17.5-27 \mathrm{~cm}$, have an 
aperture that is smaller than the disk diameter and lack windows inside the perigone tube and diaphragm. The recently described $R$. lobata from Panay (Galang \& Madulid, 2006) resembles $R$. manillana to a large extent, but is different from this species and others, including $R$. banahaw, by its lobed diaphragm.

In gross morphology, $R$. banahaw more closely resembles $R$. baletei from the Bicol region, Camarines Sur Province in southern Luzon. It differs from this species, however, in its generally larger flowers $(15-16(-22) \mathrm{cm}$ in $R$. baletei), more confluent wart ornamentations, whitish colour of the aperture rim, and darker coloured and more numerous and densely packed processes. As opposed to $R$. baletei, these processes are more obviously branched and interspersed with many smaller tuberculate processes. In addition, $R$. banahaw has glabrous ramenta which are grouped in dense clusters inside the diaphragm and are more or less solitary in the perigone tube, whereas the ramenta of $R$. baletei are sparsely and minutely pubescent and distributed more uniformly. Furthermore, $R$. banahaw usually has more numerous, less exposed anthers.

Rafflesia banahaw also shows some resemblance to the similarly-sized $R$. tengkuadlinii Mat-Salleh \& Latiff from Borneo. This species, however, has flowers that are uniformly dull to bright orange without whitish warts on their perigone lobes. Rafflesia tengku-adlinii also differs in the shape and organization of the processes, in which it resembles $R$. baletei more closely.

\section{Conservation}

The Mt Banahaw mountain range is a popular destination for various religious sects and mountaineering groups. In the past, this area has attracted hundreds of thousands of visitors each year, which resulted in large-scale destruction and disturbance of its forests. In 2004, the Mt Banahaw-San Cristobal landscape was declared a protected area and was closed for the public to rehabilitate the mountain.

It is surprising that $R$. banahaw has never been noticed during nearly a century and a half of botanical exploration, pilgrimages, and mountaineering activities. Perhaps the absence of $R$. banahaw from the many historical plant collections from the Mt Banahaw area (e.g., by Weiss in the year 1870, Vidal in 1884, Whitford in 1904, Elmer in 1906 and 1907, Foxworthy in 1907, Copeland in 1909 and 1933, and Merrill in 1911) indicates that its host plant may have been previously much less common in the area. Tetrastigma generally grows along forest edges, riverbanks, and other places where sufficient light exists for seed germination (Meijer, 1997; Nais, 2001). Because of increased human activity, suitable habitats for Tetrastigma may currently be more common on Mt Banahaw than in the days of Elmer and Copeland when the forest was less fragmented and disturbed. Despite more favourable conditions for Tetrastigma, large-scale disturbance of these sites by frequent visitors may have prevented Rafflesia from reaching a reproductive stage for many years, thus reducing the chances of discovery during the past 50 years. The recent finding of Rafflesia in the area comes after three years of protection against unsustainable tourism and pilgrimage and may be a sign that the forests on Mt Banahaw are recovering.

Despite these positive signs, $R$. banahaw is still critically endangered. Populations contain a relatively high number of dead buds that had reached advanced stages of development and very few flowers in anthesis. This may be due to both anthropogenic and natural disturbance. In one population, its host (Tetrastigma sp., Barcelona, Cajano \& 
Mendua 3346 and 3347, PNH, CAHUP) was damaged by a recent typhoon and the most prolific Rafflesia population is right beside a main trail, close to a popular campsite and near a landslide.

Specimens studied:

PHILIPPINES. Luzon, Quezon Prov., Dolores Municipality, Barangay Kinabuhayan, Mt Banahaw: Barcelona, Cajano \& Mendua 3345 (holo PNH; iso CAHUP); Barcelona, Cajano \& Mendua 3348 (PNH); Barcelona 3351 with Mendua (PNH); Barcelona, Cajano \& Mendua 3349 (PNH); Barcelona, Cajano \& Mendua 3350 (CAHUP).

\section{ACKNOWLEDGEMENTS}

We dedicate Rafflesia banahaw to the beautiful people of Mt Banahaw. We thank the environmentalists of Tanggol Kalikasan for providing us with the first colour photos of the flower they encountered in 2006 and bringing the Banahaw Rafflesia to our attention. One of their members, Jay Lim, together with local officials headed by Barangay Captain Angeles Coronado, staff of the Department of Environment and Natural Resources (DENR) office and the Protected Areas Management Board led by the Mt Banahaw Park Superintendent Salud Pangan assisted us during our first visit of the site. We also thank the staff of the DENR Provincial Office and especially the Provincial Environment and Natural Resources Officer (PENRO) Herminigildo Jocson, Noel Recillo, Magtanggol and Josephine Barrion for helping us describe the Rafflesia habitat by providing tree identifications, staff of the DENR's Protected Area and Wildlife Bureau (DENR-PAWB), Director Mundita S. Lim, Asst. Director Manuel V.A. Bravo, Antonio C. Manila, and Anson Tagtag for facilitating issuance of Gratuitous Collecting and Transport Permits. We thank the National Museum of the Philippines and the University of the Philippines Natural History Museum (UPMNH) for financial assistance, Nemesio M. Diego Jr. for scientific illustrations and Michael G. Price for providing the Latin diagnosis. Lastly, we express our sincere gratitude to our local guides and field assistants Jerry Mendua and Ananias (Dingdong) Cahilo and to the Coronado family for accommodation during our stay.

\section{REFERENCES}

Barcelona, J.F., M.O. Cajano \& A. S. Hadsall. 2006. Rafflesia baletei, another new Rafflesia (Rafflesiaceae) from the Philippines. Kew Bull. 61: 231-237.

Barcelona, J.F. \& E.S. Fernando. 2002. A new species of Rafflesia (Rafflesiaceae) from Panay Island, Philippines. Kew Bull. 57: 647-651.

Davis, C.C., M. Latvis, D.L. Nickrent, K. J. Wurdack \& D.A. Baum. 2007. Floral gigantism in Rafflesiaceae. Science 315: 1812.

Fernando, E. S. \& P.S. Ong. 2005. The genus Rafflesia R.Br. (Rafflesiaceae) in the Philippines. Asia Life Sci. 14: 263-270.

Galang, R. \& D.A. Madulid. 2006. A second new species of Rafflesia (Rafflesiaceae) from Panay Island, Philippines. Folia Malaysiana 7: 1-8.

Madulid, D.A., D. Tandang \& E.M.G. Agoo. 2006 ('2005’). Rafflesia magnifica (Rafflesiaceae), a new species from Mindanao, Philippines. Acta Manilana 53: 1-6.

Meijer, W. 1997. Rafflesiaceae. Flora Malesiana, Ser. I, 13: 1-42.

Nais, J. 2001. Rafflesia of the world. Sabah Parks, Kota Kinabalu. 